\title{
Patronage and perceived efficacy of herbal antityphoid preparations, and anti-salmonella activity of a herbal preparation used in Ghana
}

\author{
George A Koffuor ${ }^{1 *}$, Akua Afriyie Abruquah ${ }^{2}$, Rauf Audu ${ }^{3}$, John Amoah $^{1}$, Davina Agwah ${ }^{1}$ \\ ${ }^{1}$ Department of Pharmacology, Faculty of Pharmacy and Pharmaceutical Sciences, Kwame Nkrumah University of Science and Technology, Kumasi, \\ Ghana. ${ }^{2}$ Department of Pharmaceutical Sciences, Faculty of Health Sciences, Kumasi Polytechnic, Kumasi, Ghana. ${ }^{3}$ Kama Health Service, Kwame \\ Nkrumah University of Science and Technology, Kumasi, Ghana.
}

\begin{tabular}{l}
\hline ARTICLE INFO \\
\hline Article history: \\
Received on: $27 / 11 / 2015$ \\
Revised on: $22 / 12 / 2015$ \\
Accepted on: 08/01/2016 \\
Available online: $30 / 03 / 2016$ \\
\hline Key words: \\
Broth dilution method; \\
Ciprofloxacin; Minimum \\
Inhibitory Concentration; \\
Salmonella typhi; Vernonia \\
amygdalina.
\end{tabular}

\begin{abstract}
Objectives: To assess the patronage, and the perceived efficacy of herbal preparations in the treatment of typhoid fever, and to ascertain the anti-salmonella activity of a herbal preparation used as an antityphoid in Ghana. Materials and Methods: Purposively and conveniently from 700, 65 individuals who had had typhoid fever (clinically confirmed) were sampled. Well-structured questionnaires on the subject were administered to sampled individuals. Experimentally, the Minimum Inhibitory Concentration (MIC) of a herbal antityphoid preparation on Salmonella typhi was determined using the broth dilution method. Results: 46/65 (70.8\%) used herbal preparations (19 used pre-packaged products; 27 used extemporaneous preparations) while 19/65 (29.2\%) used orthodox drugs to treat their infection. Some of the herbs commonly used were Nauclea latifolia, Morinda lucida, Paullinia pinnata, Vernonia amygdalina, Cassia alata, Phyllantus fraternus, Azadirachta indica, Mangifera indica, and Carica papaya. Majority, $42 / 45$ (91.3\%), recovered after the use of the herbal antityphoid products (laboratory confirmation), 7/42 (15.2\%) had relapse within three months, 9/45 (19.6\%) experienced mild side effects. Experimentally, both the prepared herbal mixture and ciprofloxacin had MICs of 4 and $2 \mu \mathrm{g} / \mu \mathrm{l}$ respectively. Conclusion: Herbal anti-typhoid preparations are highly patronized and have been found to be efficacious. Experimentally the herbal mixture prepared showed interesting anti-salmonella activity.
\end{abstract}

\section{INTRODUCTION}

Typhoid fever, a potentially life-threatening gastrointestinal infection, is caused by a non-spore-bearing bacilli called Salmonella enterica serovar Typhi (S. typhi) (Santos et al., 2001). This bacterium is transmitted by the orofecal route with the organism gaining entry into the body through the intestinal mucosa in the region of the Peyer's patches (Ochiai et al., 2008). Advances in public health strategies, technology, and hygiene have led to the eradication of typhoid fever from the developed world but since the 1800s, typhoid fever has remained an endemic disease in many developing countries (Ashbolt, 2004; Bhutta and Dewraj, 2006). This is worrying because of

* Corresponding Author

George Asumeng Koffuor, Department of Pharmacology, Faculty of

Pharmacy and Pharmaceutical Sciences, Kwame Nkrumah University of Science and Technology, Kumasi, Ghana. Email: gkoffuor[at]yahoo.com typhoid fever associated morbidity and mortality (Crump, 2004) particularly in children younger than 5 years (Sinha et al., 1999, Siddiqui et al., 2006), as well as the emergence of multidrugresistant (MDR) Salmonella typhi strains against first line antimicrobials such as Ampicillin, Chloramphenicol, and Cotrimoxazole (Rowe et al., 1997; Renuka et al., 2005; Bhutta and Dewraj, 2006; Bhutta, 2006).

The sources of infection vary but the commonest mode of transmission is by ingesting an infective dose of S. typhi through food or water contaminated with feces or urine of a patient or carrier. The true global disease burden of typhoid fever is difficult to estimate as few established surveillance systems on typhoid fever exist in developing countries (Bhutta and Dewraj, 2006). For example, in Africa the overall burden of typhoid fever remains largely unknown, mainly because facilities capable of performing the blood culture tests essential for diagnosis are absent from many regions (Mweu and English, 2008). 
Typhoid fever like malaria and schistosomiasis, is one of the commonest febrile illnesses in developing countries (Hathout, 1970; Nsutebu, 2003; Ochiai et al., 2008). Factors that influence the extent and the overall clinical outcome of the disease include the patient's age and or immune status, vaccination history, the amount of inoculum ingested, the choice of antimicriobial agent as well as rising antimicrobial resistance which has led to increased disease related hospitalization and complications (Sinha et al., 1999; Brooks et al., 2005; Siddiqui et al., 2006). Untreated typhoid fever can lead to gruelling complications such as gastrointestinal haemorrhage, ileal perforation, hepatomegaly, anorexia, diarrhoea, toxicity, encephalopathy, myocarditis and disseminated intravascular coagulation (McConkey, 2002, Mert et al., 2004). For decades, the antibiotics Chloramphenicol, Ampicillin, and Cotrimoxazole were the mainstay of typhoid treatment (Acharya et al., 1995). However, the widespread emergence of multidrug-resistant (MDR) S. typhi strains necessitated the search for other therapeutic alternatives such as the fluoroquinolones (Ciprofloxacin, Norfloxacin, and Ofloxacin), the third generation cephalosporins (e.g. Ceftriazone), and the azalides (e.g. azithromycin) (Mirza et al., 1996). Flouroquinolones are however restricted from routine use in children and quinoloneresistant $S$. typhi strains have been documented (Wallace et al., 1993; Wain et al., 1996; Vinh et al., 1996). Ceftriazone is highly effective against $S$. typhi but parenteral administration limits its usage (Wallace et al., 1993). Azithromycin is however very effective against $S$. typhi (Butler and Girard, 1993). These drugs are very expensive and less affordable to a majority of individuals in developing countries such as Ghana, hence a greater proportion of the population resort to the use of herbal medicines which are generally affordable and easily accessible to the majority. It is estimated that about $80 \%$ of the world's population rely on traditional medicine particularly herbal medicine for primary health care because of less side effect profile, better compatibility with the human body, efficacy and better cultural acceptability (Gijtenbeek et al., 1999, Abbiw et al., 2002, WHO, 2003). Ghana is a land of immense biodiversity and a hub of very potent and efficacious herbal medicines which are involved either in the holistic treatment of diseases or in the alleviation of symptoms. An impressive number of plants have been used traditionally in the treatment of typhoid fever in Africa and in Ghana since time immemorial such as Vernonia amygdalina (Asteraceae), and Nauclea latifolia (Rubiaceae) (Omobuwajo et al., 2008). This study involving a survey, and laboratory investigation was therefore carried out to assess the patronage and perceived efficacy of herbal preparations in the treatment of typhoid fever and to ascertain the anti-salmonella activity of a herbal preparation used as an antityphoid drug in Ghana.

\section{METHODOLOGY}

\section{Study area}

The study was conducted at Asafo, Ayigya, Adum and Bantama which are suburbs in Kumasi, the capital of the Ashanti
Region of Ghana. These areas were selected because they are densely populated with people from different ethnic groups and cultural diversity, high commercial activity and well established industries.

\section{Sampling technique and sample size}

Non-probability and random sampling sampling methods were used to sample 700 individuals who were randomly interviewed to ascertain that the individual had had typhoid fever before. Of these, 65 individuals were purposively and conveniently sampled to participate in this study.

\section{Inclusion criteria}

A total of sixty five individuals were selected for this study based of the following;

- The individuals had been laboratory diagnosed of typhoid fever within the last five years.

- $\quad$ The individual was presently diagnosed with typhoid fever.

- The individuals used either herbal remedies, orthodox/ allopathic medicine or both for the treatment of the disease before but at different times.

\section{Exclusion criteria}

After the preliminary interview, most individuals were excluded from the study because those individuals;

- Had not been laboratory diagnosed of typhoid fever in the last five years.

- Had been presumptively diagnosed with typhoid fever.

- Had been laboratory diagnosed of typhoid fever but had used only orthodox/allopathic drugs for treatment.

- Only knew about typhoid fever and its symptoms.

- Knew the herbal drugs for typhoid fever but had not used any of them before in therapy.

\section{Study design}

A well-structured questionnaire designed to include close and open ended questions was pretested on a convenient sample of 10 individuals for easy comprehension and easy readability. Semistructured interviews were conducted (between November 2013 and March, 2014) in twi (the local language of the indigenous people; which is spoken and understood by all) where necessary after verbal consent was sought from participants.

\section{Study variables}

Data gathered from respondents included their bio-data, choices of drugs (herbal or orthodox medicines), patronage of herbal anti-typhoid preparation, how long herbal antityphoid drugs had been used by the respondents, names of herbs used, and perceived efficacy of anti-typhoid herbal preparation, among others. 


\section{Data analysis}

The data obtained from respondents were analyzed using SPSS (Statistical Package for Social Scientists) version 20.0 for windows. Graphs were drawn with GraphPad prism Version 6 (GraphPad Software, San Diego California USA, www.graphpad.com).

\section{Anti-salmonella activity of a herbal antityphoid drug}

\section{Preparation of the herbal antityphoid product (NCVP)}

This formula was provided by Adutwumwaa Herbal Industries Limited, Abuakwa, Kumasi, in the Ashanti Region of Ghana; a manufacturer of prepackaged herbal products. The plant parts of Nauclea latifolia (roots), Cassia alata (leaves), Vernonia amygdalnas (leaves) and Phyllantus fraternus (leaves) were obtained from Techiman, in the Brong Ahafo Region of Ghana. These were selected based on the most common herbs mentioned by respondents.

The plants were authenticated by a Pharmacognosist, in the Department of herbal medicine, KNUST, Ghana. The plant parts as outline above were quantified in the ratio of 10:1:1:1 respectively, combined and boiled for two hours with 10.5 litres of water. The herbal preparation was evaporated to dryness in a hot air oven at $40{ }^{\circ} \mathrm{C}$.

The weight of sample before drying was $90.59 \mathrm{~g}$ and the percentage yield after evaporation to dryness was $16.82 \%$. The dry powder, labelled NCVP, was stored in a dessicator and portions of it reconstituted in sterile water for use in this study.

\section{Drugs Used}

Ciprofloxacin hydrochloride (Denk Pharma GmbH \& Co. KG., Germany) was used as the reference anti-salmonella drug.

\section{Determination of anti-salmonella activity of NCVP}

The broth dilution method was employed in the determination of Minimum Inhibitory Concentration (MIC), using a $200 \mu \mathrm{l}$ volume 96 well microtitre plate. A stock solution of NCVP of concentration $256 \mu \mathrm{g} / \mu \mathrm{l}$ was prepared. From this, $200 \mu \mathrm{l}$ dilute solutions of NCVP of concentrations 1, 2, 4, 8, 16, 32, 64, and $128 \mu \mathrm{g} / \mu \mathrm{l}$ were prepared using $80 \mu \mathrm{l}$ of double strength nutrient broth, $10 \mu \mathrm{l}$ of $S$. typhi suspension, a volume of the NCVP stock solution, and sterile water to make up to volume. The same was done for ciprofloxacin $(1,2,4,8,16,32,64$, and $128 \mu \mathrm{g} / \mu \mathrm{l})$; the reference anti-salmonella antibiotic used. The mixtures were incubated for 48 hours at $37^{\circ} \mathrm{C}$ and the MICs estimated.

\section{RESULTS}

Demographic characteristics of sampled population

Of the 65 respondents who had ever had typhoid fever before, $34(52 \%)$ were male while $31(48 \%)$ were female. The modal age $(25 ; 38.5 \%)$ was $31-40$ years. The majority $34(52.3 \%)$ of the respondents were traders (Table 1$)$.

\section{Patronage of herbal anti-typhoid preparation}

Results indicate that $46(70.8 \%)$ [25 males, 21 females], used herbal anti-typhoid preparations while 19 (29.2\%) were using orthodox drugs. Of the 46 using herbal preparations, 19 (41.3\%) used pre-packaged herbal products, while $27(58.7 \%)$ used extemporaneous preparations made from various combinations of herbs and leaves listed in Table 2. Data on patronage did not seem to differ significantly among gender however the 21-30 and the $31-40$ year ranges had $64.7 \%$ and $60 \%$ patronage respectively. All the unemployed, as well as majority of civil servants $(83.3 \%)$ and traders $(76.5 \%)$ patronized herbal preparations (Table 3 ).

\section{How long individuals had used herbal antityphoid drugs}

The highest recorded time for which herbal anti-typhoids have been used by respondents anytime they had typhoid fever, after being introduced to it, was 8 years and this was by $2(4.3 \%)$ respondents. The least duration of time was within three months and this was by $7(15.2 \%)$. The majority $12(26.1 \%)$ of respondents had used these within four to six months after being introduced as this was their first time of having the disease (Table 4).

\section{Perceived efficacy of anti-typhoid herbal preparation}

While majority, 42 (91.3\%), recovered after the use of the herbal anti-typhoid products (according to medical laboratory confirmation), six $(8.7 \%)$ did not recover. Seven $(15.2 \%)$ had relapse of the disease; two after one month, and five, within three months. Nine (19.6\%) experienced side effects (i.e. two, three, and four experienced dizziness, diarrhea, and vomiting respectively) after the use of the herbal anti-typhoid products but these were not severe (the diarrhea, and vomiting were self-limiting). Thirtyseven $(80.4 \%)$ experienced no side effects.

\section{Combination of herbal and orthodox antityphoid products}

Based on the result obtained from combination of herbal and orthodox antityphoid drugs, $14.3 \%$ of the users of herbal antityphoid products combined theirs with orthodox drugs while $85.7 \%$ used only herbal antityphoid products.

Table 1: Age and employment status of 65 respondents used in the study on the patronage and perceived efficacy of herbal preparations used in the treatment of typhoid fever in Kumasi, Ghana.

\begin{tabular}{cccccc}
\hline Gender & Frequency/ percentage & Age range & Frequency/ Percentage & Occupation & Frequency/ Percentage \\
\hline Males & $34(52 \%)$ & $11-20$ & $12(18.5 \%)$ & Farmers & $3(4.6 \%)$ \\
Females & $31(48 \%)$ & $21-30$ & $17(26.2 \%)$ & Traders & $34(52.3 \%)$ \\
& & $31-40$ & $25(38.5 \%)$ & Civil servant & $6(9.2 \%)$ \\
& & $41-50$ & $10(15.4 \%)$ & Unemployed & $3(4.6 \%)$ \\
& & 150 & $1(1.5 \%)$ & Student & $17(29.2 \%)$ \\
\hline
\end{tabular}


Table 2: Herbs used for the prepackaged extemporaneous preparations used by respondents.

\begin{tabular}{|c|c|c|c|}
\hline Herbs & & & \\
\hline Botanical names & Vernacular/local name & Frequency & Percentage \\
\hline Nauclea latifolia & Kankanu & 14 & 30.4 \\
\hline Morinda lucida & Konkronma & 19 & 41.3 \\
\hline Citrus aurantifolia & Ankaadwea & 7 & 15.2 \\
\hline Persia americana & Paya & 9 & 19.6 \\
\hline Paullinia pinnata & Tuantini & 11 & 23.9 \\
\hline Ricinodendron heudelotii & Wan ma & 2 & 4.3 \\
\hline Alchornea cordifolia & Agyamma & 3 & 6.5 \\
\hline Picralima nitida & Zkuamen & 5 & 10.9 \\
\hline Terminalia superba & $\xi$ fram & 1 & 2.1 \\
\hline Rauwolfia vomitoria & Kakapenpen & 11 & 23.9 \\
\hline Mangifera indica & Amango & 8 & 17.4 \\
\hline Trichilia ornithothera, & Tanuro niniakra & 2 & 4.3 \\
\hline Vernonia amygdalina & Anwowene & 19 & 41.3 \\
\hline Cassia alata & Simpe & 15 & 32.6 \\
\hline Phyllantus fraternus & Ab $\xi$ wommaguwakyi & 12 & 26.1 \\
\hline Azadirachta indica & Nim tree & 16 & 34.7 \\
\hline Carica papaya & $\mathrm{B} \xi \xi \mathrm{frZ}$ & 15 & 32.6 \\
\hline Spathodea campaulata & Kuakuanusu & 3 & 6.5 \\
\hline Antholeisia nobilis & छkuafo kZtZ & 1 & 2.1 \\
\hline Cymbopogon citrates & Tee sare & 3 & 6.5 \\
\hline
\end{tabular}

The names of the herbs were obtained from the list of active ingredients on the products mentioned by the respondents themselves. Respondents gave vernacular names which were translated into their botanical names.

Table 3: Data on the frequency and the percentage patronage of the 46 individuals who used herbal antityphoid drugs to treat typhoid fever.

\begin{tabular}{|c|c|c|c|c|c|c|c|c|}
\hline Gender & $\begin{array}{l}\text { Frequency/ } \\
\text { percentage }\end{array}$ & $\%$ patronage & Age range & $\begin{array}{l}\text { Frequency/ } \\
\text { Percentage }\end{array}$ & $\%$ patronage & Occupation & $\begin{array}{l}\text { Frequency/ } \\
\text { Percentage }\end{array}$ & $\%$ patronage \\
\hline Males & $25(54.3 \%)$ & 73.5 & $11-20$ & $12(26.1 \%)$ & 100 & Farmers & $2(4.3 \%)$ & 66.7 \\
\hline \multirow{4}{*}{ Females } & $21(45.7 \%)$ & 67.8 & $21-30$ & $11(23.9 \%)$ & 64.7 & Traders & $26(56.5 \%)$ & 76.5 \\
\hline & & & $31-40$ & $15(32.6 \%)$ & 60 & Civil servant & $5(10.9 \%)$ & 83.3 \\
\hline & & & $41-50$ & $10(15.2 \%)$ & 100 & Unemployed & $3(6.5 \%)$ & 100 \\
\hline & & & $>50$ & $1(0.02 \%)$ & 100 & Student & $10(21.7 \%)$ & 52.6 \\
\hline
\end{tabular}

Table 4: How long respondents have been using herbal anti-typhoid drugs to treat typhoid fever after being introduced to it.

\begin{tabular}{lcc}
\hline Time period & Frequency $(\mathbf{n})$ & Percentage (\%) \\
\hline $0-3$ months & 7 & 15.2 \\
$4-6$ months & 12 & 26.1 \\
$7-9$ months & 7 & 15.2 \\
$10-12$ months & 5 & 10.9 \\
2 years & 4 & 8.7 \\
4 years & 6 & 13.0 \\
7 years & 3 & 6.2 \\
8 years & 2 & 4.3 \\
Total & 46 & 100.0 \\
\hline
\end{tabular}

Table 5: Minimum Inhibitory Concentration of ciprofloxacin and herbal antityphoid product (NCVP) on growth of Salmonella typhi in the broth dilution method.

\begin{tabular}{|c|c|c|c|c|c|c|c|c|}
\hline \multirow[b]{2}{*}{ Wells } & \multicolumn{8}{|c|}{ Concentration $(\mu \mathrm{g} / \mu \mathrm{l})$} \\
\hline & 1 & 2 & 4 & 8 & 16 & 32 & 64 & 128 \\
\hline \multicolumn{9}{|c|}{ NCVP (Decoction) } \\
\hline A & + & + & - & - & - & - & - & - \\
\hline B & + & + & - & - & - & - & - & - \\
\hline $\mathrm{C}$ & + & + & - & - & - & - & - & - \\
\hline $\mathrm{D}$ & + & - & - & - & - & - & - & - \\
\hline \multicolumn{9}{|c|}{ Ciprofloxacin hydrochloride } \\
\hline $\mathrm{E}$ & + & - & - & - & - & - & - & - \\
\hline $\mathrm{F}$ & + & - & - & - & - & - & - & - \\
\hline G & + & - & - & - & - & - & - & - \\
\hline $\mathrm{H}$ & + & - & - & - & - & - & - & - \\
\hline
\end{tabular}

The '-' (negative sign) used signifies the inhibition of the bacteria Salmonella typhi at the different concentrations. The '+' (positive sign) used signifies the presence of the bacteria Salmonella typhi at the different concentrations.

\section{Anti-salmonella activity of NCVP}

At concentrations of $4,8,16,32,64$, and $128 \mu \mathrm{g} / \mu \mathrm{l}$, there was complete inhibition in growth of Salmonella typhi by both NCVP and ciprofloxacin in all the wells (A-H). At concentration
$2 \mu \mathrm{g} / \mu \mathrm{l}$, there was also inhibition of growth of the organism by Ciprofloxacin in wells E-H. For the concentration $1 \mu \mathrm{g} / \mu \mathrm{l}$, there was presence of growth in all the wells $(\mathrm{A}-\mathrm{H})$ for both NCVP and Ciprofloxacin (Table 5). 


\section{DISCUSSION}

The vast contribution of traditional medicine to the wellbeing and the improvement in the quality of life of the African particularly the Ghanaian cannot be overemphasized. Despite the numerous challenges facing traditional medicine use globally such as standardization, stability and quality control issues, traditional medicines have managed to thrive well through the years (Sen et al., 2011; Gyasi et al., 2015). Based on this background, this study was conducted to ascertain the perceived efficacy and hence the patronage of herbal preparations used in the management of typhoid fever, and to ascertain the anti-salmonella activity of a herbal preparation used as an antityphoid drug in Kumasi, the second largest city in Ghana.

Of 65 purposively sampled individuals who had typhoid fever, males were more than females $(52 \%: 48 \%)$. Evidence exists to support this distribution, that typhoid fever is more prevalent in males than females (Hosoglu et al., 2004). The exact reason for this male predisposition to the infection is not well known although it is possible that males have an increased exposure to unsafe drinking water and food than females (Whitaker et al., 2009). More than half (64.7\%) of the respondents were between 20 - 40 years which was in line with findings from previous studies. For instance, the study by Akinyemi et al., (2000) on antibacterial screening of five Nigerian medicinal plants used against $S$. typhi and S. Paratyphi showed that young adults were more predisposed to the infection. Going about their normal daily activities, young adults are more likely to consume food and water contaminated with $S$. typhi strains, or come into contact with individuals who are carriers of the disease.

Majority $(52.3 \%)$ of the respondents were traders. In Ghana, traders have a high probability of exposure to Salmonella typhi by coming into contact with carriers, ingestion of contaminated food and water, or being exposed to non-sanitary or unhygienic environments. When $S$. typhi enters the digestive system, it multiplies in the intestines and spreads rapidly throughout the blood stream causing a systemic infection with associated symptoms such as fever, headache, nausea, loss of appetite, constipation and diarrhoea (House et al., 2001). Currently, global typhoid fever prevention strategy is focused at improving sanitation by ensuring clean and safe food and good water supplies, identification and efficient treatment of chronic $S$. typhi carriers as well as the use of typhoid vaccines (Crump and Mintz, 2010).

A lot of people in Africa, and in Ghana resort to herbal medicines as their first line of treatment when they are sick (Gyasi et al., 2015). This fact has also been made evident by the findings of this study. In this study, $70.8 \%$ of the respondents with typhoid fever used herbal medicine for treatment. This is line with results of a previous study conducted in the Kumasi Metropolis and the Sekyere South District in Ghana on prevalence and pattern of traditional medical therapy utilization (Gyasi et al., 2015). Out of this number, 21 were females while 25 were males. This result showing male dominance in the use of traditional medicine is in contrast to the results of previous studies where females dominate in the use of herbal medicine (Loera et al., 2001, Adusumilli et al., 2004).

In recent times, public interest in natural remedies, mostly herbal medicine, has increased drastically not only in developing countries but also highly industrialized countries (Grunwald, 1995). This has increased international trade in herbal medicine tremendously. Self-prescribed herbal remedies are on the ascendency these days for the treatment of diseases such as headaches, insomnia, fever, malaria, intestinal disorders, typhoid fever, depression, coughs, cancer, premenstrual syndrome etc (Crag et al., 1993, Craig, 1999). Medicinal plants such as Morinda lucida, Magnifera indica, Carica papaya, Paullina pinnata, Phyllantus fraternus, Cassia alata, Veronia amydalina and Rawolfia vomitoria are very popular and have been used in the management of several diseases including typhoid fever since prehistoric times (Akinyemi, 2000; Ashafa and Olunu, 2011). The popularity and usage of these plants have been confirmed in this study as a lot of respondents alluded to the fact that they had used these medications for the management of typhoid fever. In his study, majority (76.2\%) of the respondents after being introduced to herbal anti-typhoid drugs a year had used it to treat typhoid fever (Table 4). It appears there is massive usage of herbal products in the management of both acute and chronic conditions (Zollman and Vikers, 1999, Li and Wang, 2005) and this has been evidenced in this study as $2(4.3 \%)$ had used herbal anti-typhoid preparations, anytime they had the infection, for about 8 years.

It is known that factors considered in selecting herbal medicine as a choice of treatment include the efficacy of the medicine, affordability, convenience and easy accessibility (Eddouks et al., 2002). Due to the known and documented side effects caused by synthetic products, herbal products are now moving from fringe to mainstream use with a lot of people seeking health remedies from natural products (Johnson and William, 2002). Herbal products which were hitherto confined to health food shops are now marketed in a lot of pharmacies. Whereas some herbal products contain physiologically safe and beneficial active constituents, others may not be unsafe to use. Some herbs are classified as unsafe even in minute quantities by the Food and Drug Administration (Larkin, 1983, Saxe, 1987). Natural medicinal plants are however in danger of extinction due to unscrupulous harvesting techniques and loss of growth habitat. During the collection of medicinal products for curative purposes, the season, age of the plant, storage conditions, and temperature play an indispensable role in its potency.

The fact that $91.3 \%$ of users of herbal anti-typhoid preparations have recovered (confirmed by medical laboratory tests) after use support the findings of several studies done to prove the efficacy of herbal anti-typhoid products (Ernst, 2005, Bent, 2008). It is generally believed that herbal preparations are pure because they are prepared using natural bases without any additives. However, there is limited scientific evidence to ascertain the safety and side effect profile of most herbal products (Bent, 2008). In this study, 9 (19.6\%) experienced mild side effects after 
using herbal anti-typhoid products. Side effects of herbal preparations can range from relatively mild ones such as diarrhea, vomiting and dizziness as reported in this study to more serious and complex ones such as hepatotoxicity, precipitous labor, tetanic uterine contractions, hyperthermia, hypertension, seizures and coma as reported in previous studies (MacGregor et al., 1989, McFarlin et al., 1999; Wells and Bjorksten, 1989).

Attempts have been made to integrate traditional and orthodox medical systems although it has seen much difficulty. Polytherapy is indicated as a good pharmaceutical principle however, further studies are needed to ascertain the relative advantage of polytherapy (Ebong et al., 2008). Polyherbal therapy is also recommended as a good pharmaceutical principle because of its advantage of producing maximum therapeutic efficacy with minimum side effects (Ebong et al., 2008, Chan, 2003). Out of the total users of the herbal anti-typhoid products, $14.3 \%$ combined theirs with orthodox medicine.

The herbal anti-typhoid mixture tested for antisalmonella activity contained Vernonia amygdalina, Cassia alata, Phyllanthus fraternus and Nauclea latifolia in a ratio of 1:1:1:10 respectively. These herbs have good antibacterial activity especially against gram negative bacteria, analgesic, anti-diabetic, anthelmintic, anticancer, antimalarial, antioxidant and antiinflammatory properties. This is because they contain flavonoids, sesquiterpine lactones, saponins, tannins, alkaloids and sterols in varying degrees (Ebong et al., 2008, Abosi and Raseroka, 2003, Akah and Okafor, 1992).

In vitro studies was carried out to prove the efficacy of the herbal anti-typhoid preparation by cultivating $S$. typhi on bismuth sulphite agar. The presence of $S$. typhi was confirmed by the growth of silver rabbit eyed colonies on the agar. Isolation of $S$. typhi was done by sub-culturing into a test tube containing nutrient broth which had a cloudy top indicating growth of viable organisms.

Ciprofloxacin, which is a fluoroquinolone, was used as a standard solution as it is one of the leading orthodox drugs used in the treatment of typhoid fever. Using the broth dilution method, ciprofloxacin inhibited $S$. typhi at a minimum concentration of 2 $\mu \mathrm{g} / \mu \mathrm{l}$ while the herbal mixture inhibited the organism at $4 \mu \mathrm{g} / \mu \mathrm{l}$ indicating that ciprofloxacin is more potent than the plant extract. Also, ciprofloxacin had higher antimicrobial activity than the herbal mixture.

In addition to the increasing complexity of managing typhoid fever because of antimicrobial resistance, there is a strong case for much greater effort in disease control through improvements in sanitation, greater access to safe water and food, identification and treatment of $S$. typhi carriers and more widespread use of currently available vaccines in populations at high risk of infection.

\section{CONCLUSION}

Herbal anti-typhoid preparations are highly patronized and have been reported to be efficacious in the treatment of typhoid fever. Experimentally the herbal mixture prepared from Vernonia amygdalina, Cassia alata, Phyllanthus fraternus, and Nauclea latifolia showed anti-salmonella activity by inhibiting the growth of Salmonella typhi at a Minimum Inhibitory Concentration of $4 \mu \mathrm{g} / \mu \mathrm{l}$.

\section{ACKNOWLEDGEMENT}

Our sincere thanks goes to Madam Adutwumwaa, CEO, Adutwumwaa Herbal Industries Limited, Abuakwa, Kumasi, Mr Francis Kwabena Amankwah; Technician at the Department of Pharmaceutical Microbiology, Faculty of Pharmacy and Pharmaceutical Sciences, KNUST for his immense support throughout this work, and to Mr Clifford Asare, Technician, Department of Herbal Medicine for translating the vernacular names of the herbs to their botanical names.

\section{REFERENCES}

Abbiw D, Gillett H, Agbovie T, Akuetteh B, Amponsah K and Afriyie, O. "Conservation and sustainable use of medicinal plants in Ghana". Cambridge: United Nations Environment Programme, 2002; 332 .

Abosi AO, Raseroka BH, Benjamin H. In vivo antimalarial activity of Veronia amygdalina. Brit J Biomed Sci, 2003; 60(2):89-91.

Acharya G, Butler T, Ho M, Sharma PR, Tiwari M, Adinkari RK, Khagda JB, Pokhrel B, Pathak UN. Treatment of typhoid fever: randomized trial of a three-day course of ceftriaxone versus a fourteen-day course of chloramphenicol. Am J Trop Med Hyg, 1995; 52: 162-5.

Adusumilli PS, Ben-Porat L, Pereira M, Roesler D, Leitman IM. The prevalence and predictors of herbal medicine use in surgical patients. JACS, 2004; 198(4): 583-90.

Akah P.A and Okafor C.L. Blood sugar lowering effect of Veronia amygdalina Del, in an experimental rabbit model. Phytother. Res, 1992; 6(3):171-3.

Akinyemi KA. Antibacterial screening of five Nigerian medicinal plants against $S$. typhi and S. Paratyphi. JNICA, 2000; 3(1): 303.

Akinyemi KO, Coker AO, Olukoya DK, Oyefolu AO, Amorighoye EP, Omonigbehin EO. Prevalence of multi-drug resistant Salmonella typhi among clinically diagnosed typhoid fever patients in Lagos, Nigeria. Zeitschrift fur Naturforschung C, 2000; 55(5-6), 489-93.

Ashafa AOT, Olunu OO. Toxicological evaluation of ethanolic root extract of Morinda lucida (L.) Benth. (Rubiaceae) in male wistar rats. JNP, 2011; 2(2): 108-14.

Ashbolt NJ. Microbial contamination of drinking water and disease outcomes in developing regions. J Toxicol, 2004; 198(1-3):229-38. Bent S. Herbal medicine in the United States: review of efficacy, safety, and regulation. J Gen. Intern. Med, 2008; 23(6): 854-9.

Bhutta ZA and Dewraj HL. "Current concepts in the diagnosis and treatment of typhoid fever”. BMJ, 2006; 333(7558):78-82.

Bhutta ZA. Typhoid fever. In: Rakel RE, Bope ET, eds. Conn's current therapy. Philadelphia PA: Saunders, 2006; 215-8.

Brooks WA, Hossain A, Goswami D, Nahar K, Alam K, Ahmed N. Bacteremic typhoid fever in children in an urban slum, Bangladesh. Emerg. Infect. Dis, 2005; 11: 326-9.

Butler $\mathrm{T}$ and Girard E. Comparative efficacies of azithromycin and ciprofloxacin against experimental Salmonella typhimurium infection in mice. J. Antimicrob. Chemother, 31(2):313-9.

Chan K. Some aspects of toxic contaminants in herbal medicines. Chemosphere, 2003; 52(9): 1361-71.

Crag GM, Schepartz SA, Suffness M, Grever MR. The taxol supply crisis: new NCI policies for handling the large-scale production of novel natural product anticancer and anti-HIV agents. J. Nat. Prod, 1993; 56: $1657-68$ 
Craig WJ. Health-promoting properties of common herbs. Am. J. Clin. Nutr, 1999; 70(3): 491-9.

Crump JA and Mintz ED. "Global trends in typhoid and paratyphoid fever". Clin. Infect. Dis, 2010; 50(2): 241-6.

Crump JA, Luby SP, Mintz ED. The global burden of typhoid fever. Bull World Health Organ, 2004; 82: 346-53.

Ebong PE, Atangwho IJ, Eyong EU and Egbung GE. The antidiabetic efficacy of combined extracts from two continental plants: Azadirachta indica (A. Juss) (Neem) and Veronia amygdalina (Del.) (African Bitter Leaf). Am J Biochem Biotechnol, 2008; 4(3): 239-44.

Eddouks M, Maghrani M, Lemhadri A, Ouahidi M.L, Jouad H. Ethnopharmacological survey of medicinal plants used for the treatment of diabetes mellitus, hypertension and cardiac diseases in the south-east region of Morocco (Tafilalet). J Ethnopharmacol, 2002; 82(2): 97-103.

Ernst E. The efficacy of herbal medicine- an overview. Fund Clin Pharmacol, 2005; 19(4): 405-9.

Gijtenbeek, JMM, Vanden Bent MJ and Vecht CJ. Cyclosporin neurotoxicity. Journal of neurotoxicity, 1999; 246: 339-46.

Grunwald J. The European phytomedicine market: figures, trends, analysis. HerbalGram, 1995; 38: 60-5.

Gyasi RM, Siaw LP, Mensah CH. Prevalence and pattern of traditional medical therapy utilization in Kumasi metropolis and Sekyere south district, Ghana. J. Ethnopharmacol, 2015; 161: 138-46.

Hathout S el-D, Abd el-Ghaffar Y, Awny AY, Hassan K. Relation between urinary schistosomiasis and chronic enteric urinary carrier state among Egyptians. Am J Trop Hyg, 1966; 15(2): 156-61.

Hathout $\mathrm{S}$ el-D. Relation of schistosomiasis to typhoid fever. $\mathrm{J}$ Egypt Public Health Assoc, 1970; 45: 145-56.

Hosoglu, S, Aldemir M, Akalin S, Geyik MF, Tacyildiz IH and Loeb M. Risk factors for enteric perforation in patients with typhoid fever. Am J Epidemiol, 2004; 160(1): 46-50.

House D, Bishop A, Parry C, Dougan G and Wain J. Typhoid fever: pathogenesis and disease. Curr Opin Iinfect Dis, 2001; 14(5):573-8. Johnson WC and William OW, Warfarin toxicity. JVS, 2002; 35:413-21.

Larkin T. Herbs are often more toxic than magical. FDA Consum, 1983;17:4-11

Li X, Haiyan W. Chinese herbal medicine in the treatment of chronic kidney disease. Adv Chronic Kidney D. 2005; 12(3): 276-81.

Loera JA, Black SA, Markides KS, Espino DV and Goodwin JS. The use of herbal medicine by older Mexican Americans. J Gerontol A Biol Sci Med Sci, 2001; 56(11). Doi: 10.1093/Gerona/56.11.M714.

MacGregor FB, Abernethy VE, Dahabra S, Cobden I and Hayes PC. "Hepatotoxicity of herbal remedies". BMJ, 1989; 299: 1157.

McConkey SJ. Case series of acute abdominal surgery in rural Sierra Leone. World J Surg, 2002; 26(4):509-13.

McFarlin BL, Gibson MH, O'Rear J, Harman P. A national survey of herbal preparation use by nurse-midwives for labor stimulation. J Nurse Midwifery, 1999; 44: 205-16.

Mert A, Tabak F, Ozaras R, Aki H and Aktuglu Y. Typhoid fever as a rare cause of hepatic, splenic and bone marrow granulomas. Intern. Med, 2004; 43(5):436-9.

Mirza SH, Beeching NJ, Hart CA. Multi-drug resistant typhoid fever: a global problem. J Med Microbiol, 1996; 44: 317-9.

Mweu E and English M. Typhoid fever in children in Africa. Trop Med Int Health, 2008; 13(4):532-40.

Nsutebu EF, Martins P, Adiogo D. Prevalence of typhoid fever in febrile patients with symptoms clinically compactible with typhoid fever in Cameroon. Trop Med Int Health, 2003; 8: 575-8.

Ochiai RL, Acosta CJ, Danovaro-Holliday MC, Baiqing D, Bhattacharya SK, Agtini MD, Bhutta ZA, Canh DG, Ali M, Shin S, Wain J, Page AL, Albert MJ, Farrar J, Abu-Elyazeed R, Pang T, Galindo CM,
Seidlin Lorenz von, Clemens JD, Domi Typhoid Study Group. "A study of typhoid fever in five Asian countries: disease burden and implications for controls.” Bull World Health Organ, 2008; BLT.06.039818.

Omobuwajo OR, Alade GO, Sowemimo A. Indigenous knowledge and practices of women herb sellers of south-western Nigeria. Indian J Tradit know, 2008; 7: 505.

Renuka K, Sood S, Das BK, Kapil A. High-level ciprofloxacin resistance in Salmonella enterica serotype typhi in India. J Med Microbiol, 2005; 54: 999-1000.

Rowe B, Ward LR, Threlfall EJ. Multidrug-resistant Salmonella typhi: a worldwide epidemic. Clin Infect Dis, 1997; 24 (suppl 1): 106-9. Santos RL, Zhang S, Tsolis RM, Kingsley R, Adams GL, Baumler A. "Animal models of salmonella infections: enteritis versus typhoid fever." Microbes Infect, 2001; 3(14):1335-44

Saxe TG. Toxicity of medicinal herbal preparations. Am Fam Phys, 1987; 35:135-42.

Sen S, Raja C, De B. Challenges and opportunities in the advancement of herbal medicine: India's position and role in a global context. J Herb Med, 2011; 1(3): 67-75.

Siddiqui FJ, Rabbani F, Hasan R, Nizami SQ, Bhutta ZA. Typhoid fever in children: some epidemiological considerations. Int $\mathrm{J}$ Infect Dis, 2006; 10: 215-22.

Sinha A, Sazawal S, Kumar R, Sood S, Reddaiah VP, Singh B. Typhoid fever in children aged less than 5 years. Lancet, 1999; 354: 7347.

Zollman C, Vickers A. ABC of complementary medicine: what is complementary medicine?. BMJ, 1999; 319 (7211): 693.

Vinh H, Wain J, Vo TN, Cao NN, Mai TC, Bethel D, Nguyen TT, Tu SD, Nguyen MD, White NJ. Two or three days of ofloxacin treatment for uncomplicated multidrug-resistant typhoid fever in children. Antimicrob Agents Chemother, 1996; 40:958-61.

Wain J, Hoa NTT, Chinh NT, Vinh H, Everett MJ, Diep, TS, Day, NPJ, Solomon T, White NJ, Piddock, LJV, Parry CM. Quinoloneresistant Salmonella typhi in Vietnam: molecular basis of resistance and clinical response to treatment. Clin Infect Dis, 1997; 25: 1404-10.

Wallace MR, Yousif AA, Mahroos GA, Mapes T, Threlfall EJ, Rowe B, Hyams KC. "Ciprofloxacin verses ceftriaxone in the treatment of multiresistant typhoid fever." Eur J Clin Microbiol Infect Dis, 1993; 12 (12): 907-10.

Wells DG, Bjorksten AR. Monoamine oxidase inhibitors revisited. Can J Anaesth, 1989; 36: 64-74.

Whitaker JA, Franco-Paredes C, Del Rio C and Edupuganti S. Rethinking typhoid fever vaccines: implications for travelers and people living in highly endemic areas. J Travel Med, 2009; 16(1):46-52.

WHO (2003a). Traditional Medicine. World Health Organization Fact Sheet No134, May 2003. (Accessed from http://www.who.int/mediacentre/factsheets/2003/fs134/en/ on 11 August 2010).

WHO, in Progress Report by the director General, Document No. A44/20, 1991, World Health Organization, Geneva, 1991.

\section{How to cite this article:}

Koffuor GA, Abruquah AA, Audu R, Amoah J, Agwah D. Patronage and perceived efficacy of herbal antityphoid preparations, and anti-salmonella activity of a herbal preparation used in Ghana. J App Pharm Sci, 2016; 6 (03): 001-007. 